\title{
El Partido Comunista argentino y su estrategia sindical entre 1943 y 1946
}

\author{
The Argentine Communist Party and its union strategy \\ between 1943 and 1946
}

Diego Ceruso* - Silvana Staltari**

\begin{abstract}
Resumen: El objetivo de este trabajo es analizar el proceder del Partido Comunista argentino en el mundo sindical tras el golpe de Estado de 1943 y hasta 1946. Este proceso contiene aún múltiples aristas para indagar pues, entre otras características, ha sido evaluado en reiteradas veces en términos generales, a veces abstractos o mayoritariamente en sus aspectos políticos. Para reconstruir la propuesta partidaria sindical, resulta necesario abordar, con la adecuada lectura metodológica, los órganos oficiales del PC como Orientación, La Hora, El Patriota y Unidad Nacional. Nuestra intención recae en indagar la construcción del planteo estratégico gremial partidario frente a los cambios en el escenario político de la Argentina y la conformación de nuevos actores en el movimiento obrero. En este recorrido, buscaremos aportar a un mayor conocimiento acerca de las circunstancias en las cuales se inició la deriva de, hasta allí, unas de las principales corrientes ideológicas con inserción entre los trabajadores.
\end{abstract}

Palabras clave: Partido Comunista, sindicalismo, orígenes del peronismo, estrategia

\begin{abstract}
The objective of this paper is to analyze the performance of the Argentine Communist Party in the trade union world after the coup d'etat of 1943 and until 1946. This process still has multiple edges to investigate because, among other characteristics, it has been evaluated repeatedly in terms general, sometimes abstract or mostly in their political aspects. To reconstruct the union party proposal, it is necessary to address, with the appropriate methodological reading, the official organs of the PC such as Orientación, La Hora, El Patriota and Unidad Nacional. Our intention lies in investigating the construction of the strategic gremial party position in the face of changes in the political scenario of Argentina and the formation of new actors in the labor movement. In this journey, we will seek to contribute to a greater knowledge about the circumstances in which the drift of, until then, one of the main ideological currents with insertion among the workers began.
\end{abstract}

Keywords: Communist Party, syndicalism, origins of Peronism, strategy

Recibido: 7 mayo 2017

Aceptado: 4 septiembre 2017

* Argentino. Coautor. Profesor, Licenciado y Doctor en Historia. Investigador. CONICET/UBA. diegoceruso@gmail.com.

** Argentina. Coautora. Profesora, Licenciada, Magister y Doctoranda en Historia. UBA. silvanastal@gmail.com.

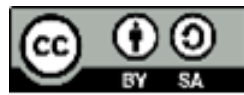


El estudio del Partido Comunista argentino (PC) en su vínculo con el sindicalismo tras el golpe de Estado de 1943 ha sido un lugar escasamente frecuentado por la historiografía. El breve balance que realizamos se inicia con los trabajos que se denominan historias "oficiales" y producciones "militantes". ${ }^{1}$ Entre ellos, el análisis más importante sobre el desempeño del PC fue el producido por el propio Partido, a través de una comisión del Comité Central. ${ }^{2}$ Con posterioridad, se elaboraron trabajos que siguieron la misma línea analítica y tendencia, realizados por otros dirigentes del Partido. ${ }^{3}$ Estos relatos poseen una característica común: la carencia de sentido crítico. En ellos la relación entre el comunismo y el movimiento obrero es revisada siempre de modo propagandístico y justificatorio y, en general, el análisis se reduce a la labor de la conducción. Las biografías, autobiografías e historias de militantes adquieren otra relevancia. ${ }^{4} \mathrm{Si}$ bien tienen el mismo vicio que las historias "oficiales", brindan especificaciones y avanzan sobre la práctica sindical comunista, área en la cual las historias oficiales se introducen sólo tangencialmente.

Otro grupo de trabajos, caracterizados como la "contra historia", producidos por ex militantes o provenientes de otras corrientes de izquierda rivales, no abordan específicamente la historia del Partido, pero critican sus posiciones. ${ }^{5}$ Materializando las tensiones y justificando sus propios itinerarios, caracterizan al accionar del PC en el período peronista como "error histórico" o "traición a la clase obrera", lo que habría imposibilitado el acercamiento a la clase trabajadora. Si los escritos "oficiales" y "militantes" deben ser matizados por apologéticos, los recaudos aquí deben ser análogos.

La centralidad que adquirió la discusión de los cientistas sociales sobre los orígenes del peronismo para encontrar las explicaciones causales del vínculo que se estableció entre el sindicalismo y aquella fuerza desacopló una visión integral del movimiento obrero y relegó la observación de las otras corrientes que continuaron trabajando en él. La serie de estudios posteriores que discuten los trabajos del sociólogo Gino Germani se centraron en el proceso formativo del vínculo, retomando sólo tangencialmente el rol y la influencia de

${ }^{1}$ En la crítica a estas historias oficiales: Georges Haupt, El historiador y el movimiento social, Madrid, Siglo XXI, 1986.

2 Partido Comunista (Comisión del Comité Central), Esbozo de Historia del Partido Comunista de la Argentina (Origen y desarrollo del Partido Comunista y del movimiento obrero y popular argentino), Buenos Aires, Anteo, 1947.

${ }^{3}$ Athos Fava, Qué es el Partido Comunista, Buenos Aires, Sudamericana, 1983; Oscar Arévalo, El Partido Comunista, CEAL, 1983; Fernando Nadra, La religión de los ateos, reflexiones sobre el estalinismo en el Partido Comunista Argentino, Buenos Aires, Puntosur, 1989.

${ }^{4}$ Entre otras: Rubens Iscaro, Historia del movimiento sindical, tomo 2, Buenos Aires, Fundamentos, 1973 (versión anterior: Origen y desarrollo del movimiento sindical argentino, Buenos Aires, Anteo, 1958); Pedro Chiarante, Pedro Chiarante, ejemplo de dirigente obrero clasista, Buenos Aires, Fundamentos, 1976; Miguel Contreras, Memorias, Buenos Aires, Testimonios, 1978.

${ }^{5}$ Rodolfo Puiggrós, Historia crítica de los partidos políticos argentinos, Buenos Aires, Argumentos, 1956; Jorge Abelardo Ramos, El partido comunista en la política argentina, Buenos Aires, Coyoacán, 1962; Juan José Real, 30 años de historia argentina (acción política y experiencia histórica), Buenos Aires-Montevideo, Actualidad, 1962. 
los comunistas. ${ }^{6}$ Desde las condiciones de posibilidades con que contó el peronismo para establecer su política en el movimiento obrero ${ }^{7}$, o desde los cambios en las posiciones internacionalistas-nacionalistas y de prescindencia-participación política de las distintas corrientes sindicales ${ }^{8}$, hasta la importancia de la construcción y mantenimiento de las lealtades políticas ${ }^{9}$ y los enfrentamientos del sindicalismo con las demás corrientes dentro las organizaciones obreras ${ }^{10}$, los comunistas son mencionados en la dinámica sindical pero sin reparar específicamente en la reconstrucción de su desenvolvimiento entre 1943 y 1946. Fue el trabajo de Marcos Schiavi acerca de los gremios textil y metalúrgico en el período 1946-1955, el que avanzó sobre el conocimiento de lo actuado por los comunistas en aquellos sectores los meses previos al triunfo electoral de Perón, aunque entendemos que aún quedan elementos que permitirían profundizar y advertir la estrategia sindical del PC en el conjunto del movimiento obrero. ${ }^{11}$

Como es conocido, el PC, en todo su período formativo como corriente (primero, como fracción de izquierda del Partido Socialista, luego, como partido socialista disidente y revolucionario, y, por último, como Partido Comunista durante su primer lustro), ocupó en el universo laboral un espacio más bien marginal. Fue a partir de mediados de los años veinte cuando la inserción obrera de los comunistas conoció un salto cualitativo. La causa fue la orientación de la "proletarización" y la "bolchevización", que les significó dotarse de un perfil obrero y la transformación de su estructura en clave jerárquica, centralizada y mayormente burocratizada, en sintonía con los postulados de una Comintern cada vez más dominada por el estalinismo. ${ }^{12} \mathrm{Si}$ el PC se convirtió en un partido apto para insertarse en el proletariado industrial, coadyuvando a su proceso de movilización y organización, fue porque se mostró bien dotado en disposiciones subjetivas (ideología, decisión y escala de valores) y en innovadores y eficaces repertorios organizacionales (células obreras y demás organismos de base). ${ }^{13}$

${ }^{6}$ Gino Germani, "El surgimiento del peronismo: el rol de los obreros y de los migrantes internos", Manuel Mora y Araujo e Ignacio Llorente (comps.), El voto peronista. Ensayos de sociología electoral argentina, Buenos Aires, Sudamericana, 1980, 87-163.

${ }^{7}$ Miguel Murmis y Juan Carlos Portantiero, Estudios sobre los orígenes del peronismo. [Edición definitiva] (1971), Buenos Aires, Siglo Veintiuno Editores Argentina, 2004.

${ }^{8}$ Hiroshi Matsushita, Movimiento Obrero Argentino, 1930-1945: Sus proyecciones en los orígenes del peronismo, Buenos Aires, Hyspamérica, 1986.

9 Juan Carlos Torre, La vieja guardia sindical y Perón. Sobre los orígenes del peronismo, Buenos Aires, Sudamericana, 1990; Louise Doyon, Perón y los trabajadores. Los orígenes del sindicalismo peronista, $1943-$ 1955, Buenos Aires, Siglo Veintiuno Editora Iberoamericana, 2006.

${ }^{10}$ Hugo del Campo, Sindicalismo y peronismo. Los comienzos de un vínculo perdurable (1983), Buenos Aires, Siglo Veintiuno Editores, 2005; Torcuato Di Tella, Perón y los sindicatos. El inicio de una relación conflictiva, Buenos Aires, Ariel, 2003.

${ }^{11}$ Marcos Schiavi, El poder sindical en la Argentina peronista (1946-1955), Buenos Aires, Imago Mundi, 2013.

12 Hernán Camarero, A la conquista de la clase obrera. Los comunistas y el mundo del trabajo en la Argentina, 1920-1935, Buenos Aires, Siglo XXI Editora Iberoamericana, 2007.

13 Ídem. Para el trabajo de base: Diego Ceruso, La izquierda en la fábrica. La militancia obrera industrial en el lugar de trabajo, 1916-1943, Colección Archivos, Buenos Aires, Imago Mundi, 2015. 
Desde mediados de los años treinta, y tras un nuevo cambio estratégico, esta vez con el 'frente popular', los comunistas plasmaron lo construido y condujeron o codirigieron relevantes sindicatos en los que confluyeron con otras fuerzas: el caso emblemático, por su poderío, fue el de la Federación Obrera Nacional de la Construcción (FONC), luego la Unión Obrera Textil (UOT), el Sindicato Obrero de la Industria Metalúrgica (SOIM), la Federación Obrera de la Industria de la Carne (FOIC), el Sindicato Único de Obreros de la Madera (SUOM) y la Federación Obrera del Vestido (FOV), principalmente. Allí impulsaron las federaciones de industria, la conformación de un sindicalismo moderno y de amplio alcance (fomentando el mutualismo, la salud, la recreación, entre otros elementos) e incluso incidieron en una cada vez más pujante Confederación General del Trabajo (CGT). ${ }^{14}$ Pero el golpe militar de junio de 1943 significó un nuevo cambio político en el país y en el movimiento obrero. La conjugación de medidas represivas, con el arresto de militantes y dirigentes comunistas, y el comienzo de una nueva proyección de relaciones entre el sindicalismo y Perón impulsada desde la Secretaría de Trabajo y Previsión (STyP), impactaron de lleno en la experiencia, notoriamente más gradual, construida por la izquierda en general, y el comunismo en particular, entre los trabajadores. De conjunto, la respuesta que el PC enarboló en el plano gremial frente a la irrupción de este fenómeno arepresenta aún un campo en el cual es posible ensayar respuestas producto de la indagación de fuentes sólo parcialmente consultadas. En línea con la estrategia de Frente Popular, los comunistas mantuvieron un discurso acorde lo requerido por la situación internacional, la lucha contra el nazi-fascismo mundial. El fascismo, identificado en clave nacional en el gobierno de 1943 y en los elementos como la policía y la Sección Especial controlada por el G.O.U. representantes de la "quinta columna dentro del Estado", debían ser resistidos desde un amplio frente de fuerzas progresistas y populares que luchasen por el retorno a la normalidad constitucional. El frentepopulismo del PC, y su vocación policlasista, situaba a la clase obrera en una alianza con sectores de la pequeña burguesía y de la burguesía nacional desvinculada del capital extranjero y la oligarquía.

A partir de lo expuesto, el interrogante que orienta nuestra investigación apunta a precisar el modo en el que el PC construyó una estrategia gremial para contrarrestar el escenario abierto tras el golpe de Estado de 1943 y cómo fue modulando respuestas concretas a los múltiples cambios que se generaron. Para ello, y a través del análisis crítico de la prensa partidaria, el trabajo se estructura en dos secciones: la primera, en donde se presentan las consecuencias inmediatas que el Partido enfrentó a partir de las medidas estatales en el mundo gremial y los realineamientos de las estructuras sindicales; en la

${ }^{14}$ Hernán Camarero, Comunismo y movimiento obrero en la Argentina, 1914-1943, tesis de doctorado, Universidad de Buenos Aires, 2008. Anteriormente, trabajos como los de Roberto Korzeniewicz y Joel Horowitz habían marcado de modo general la presencia de la militancia comunista en los gremios industriales. Ver Roberto Korzeniewicz, "Las vísperas del peronismo. Los conflictos laborales entre 1930 y 1943”, en Desarrollo Económico. Revista de Ciencias Sociales, 131, 1993, 323-354 y Joel Horowitz, Los sindicatos, el Estado y el surgimiento de Perón, 1930-1946, Buenos Aires, Eduntref, 2004. Se destaca como pionero en el tema el trabajo de Celia Durruty, Clase obrera y peronismo, Buenos Aires, Pasado y Presente, 1969. 
segunda sección, se ofrece un pormenorizado racconto acerca del modo en el que el PC diagramó una estrategia sindical en varios planos.

\section{Los comunistas frente al golpe de Estado}

El PC caracterizó el golpe, en el momento, como pro-fascista y reaccionario. La embestida anticomunista del gobierno se evidenció de inmediato, a los días se produjo el cierre del diario La Hora y luego de una reunión del ministro del Interior con los dirigentes socialistas de la CGT $\mathrm{N}^{\circ}$ 2, Francisco Pérez Leirós y Ángel Borlenghi, con quienes compartían la dirección, se ordenó su disolución. A ello sobrevino la detención de los principales dirigentes sindicales comunistas entre los que se encontraron José Peter, Pedro Chiarante, Luis Fiori, Salvador Dell'Aquila y Jorge Michellón. ${ }^{15}$ Las declaraciones del ministro del Interior Gilbert sobre la destrucción de las organizaciones comunistas y el decreto de reglamentación de las asociaciones profesionales posibilitaron por un lado, que el gobierno se hiciera con el control de los sindicatos y, por otro lado, que la ahora única CGT pudiese absorber a todo el gremialismo, incluidos los comunistas. ${ }^{16} \mathrm{Si}$ bien las relaciones de esta Central con el gobierno se tensaron con la intervención de la Unión Ferroviaria (UF) y La Fraternidad (LF), pronto Perón junto con Domingo Mercante iniciaron relaciones con los dirigentes obreros. Para el PC, el crecimiento de Perón se inscribió dentro de los continuos desplazamientos de las figuras militares, entendido como enfrentamientos entre "camarillas fascistas, con los sectores no fascistas". ${ }^{17}$ Entre el 2 y el 3 de octubre de 1943 se produjo su intervención en el conflicto de la carne con la conocida liberación y traslado desde Neuquén de Peter para que participase en la asamblea donde se levantó la medida de fuerza, aunque luego el 21 del mismo mes se clausuró el local de la FOIC. A los pocos días, Mercante asumió la intervención de la UF y LF y Perón la presidencia del Departamento Nacional del Trabajo.

Con la creación de la STyP y la reincorporación de los gremios ferroviarios a la CGT vehiculizada por Mercante, se conformó la Comisión Especial pro Unidad Sindical, integrada por sindicalistas y socialistas, algunos de los cuales comenzaron posteriormente a trabajar en vínculo con la nueva Secretaría, como Borlenghi, Luis Gay y Alcides Montiel, entre otros. Los pormenores del devenir de la relación entre la CGT, dentro de ella la UF, LF y la UTA y los dirigentes sindicalistas y socialistas, con la STyP a partir de fines de 1943 escapan a nuestro análisis específico. Acordamos con la historiografía que entiende que se fue imponiendo en aquel sector "la línea que aceptaba establecer una nueva relación entre el gobierno y el movimiento obrero, con carácter político, manifestado en forma de

${ }^{15}$ El 6 de junio fue allanado el diario del PC, el 21 del mismo mes ocurrió la entrevista de los dirigentes de la CGT $\mathrm{N}^{\mathrm{o}} 2$ con el ministro del interior Alberto Gilbert y las detenciones de los dirigentes comunistas. Del Campo, op. cit., 181.

${ }^{16}$ Del Campo, op. cit., 182-186; Matshushita, op. cit., 257-262. El decreto de reglamentación fue anulado por Perón.

${ }^{17}$ Gerónimo Arnedo Álvarez, Cinco Años de lucha, entre el X y el XI Congreso, Buenos Aires, Anteo, 1946, 29. Perón asumió el 26 de octubre y Mercante un día antes. 
adhesión al gobierno" de parte de dirigentes gremiales, que se tradujo en la obtención de más poder por parte, mayoritariamente, del sector sindicalista. ${ }^{18}$

Mientras Perón cobraba mayor relevancia como figura gubernamental, el PC trabajó en la conformación de un movimiento cívico-militar denominado Patria Libre que intentó reunir a las fuerzas de la oposición. Hacia octubre de 1944, se planteó realizar una acción insurreccional con vistas a derrocar al gobierno y frenar el aumento de poder de Perón. Aunque la propuesta fracasó, los comunistas continuaron impulsando la creación de una Junta Nacional cívico-militar y en el plano sindical organizaron el Comando Obrero Único, al que luego referiremos. ${ }^{19}$ Sobre el accionar de la STyP, manifestaron que los aumentos de salarios, y en igual orden los decretos sobre las jubilaciones, no eran medidas que representaban un mejoramiento real y estable para los trabajadores porque el movimiento inflacionario que experimentaba la economía era manejado por el gobierno en favor de los monopolios nacionales y extranjeros agudizando la "carestía de la vida". El Partido denunció que la forma selectiva e incompleta de conceder ciertas reivindicaciones históricas a los sectores populares era demagógica y corporativa y que su implementación buscaba tanto disminuir la presión de los trabajadores como profundizar las divisiones del movimiento obrero. ${ }^{20}$

La profundización del control, la centralización y la regulación de las relaciones laborales por parte del Estado, junto con la satisfacción de demandas sociales y salariales, fueron parte de la estrategia que Perón impulsó para establecer su vínculo con los trabajadores y sus organizaciones. ${ }^{21}$ Como es sabido, la contraparte de aquella estrategia incumbió la continuación de la persecución, la represión a dirigentes gremiales, militantestrabajadores del partido y el recrudecimiento de la campaña discursiva anticomunista por parte del titular de la STyP que planteaba abiertamente que "deseamos desterrar los fatídicos gérmenes que los malos políticos inocularon en los organismos gremiales para debilitarlos, fraccionarlos y explotarlos en beneficio propio" 22 , en referencia a los elementos de "ideologías extrañas" como Perón identificaba al socialismo y al comunismo y que denunciaba como "los falsos apóstoles que se introducen en el gremialismo para medrar con el engaño y la traición a las masas, y las fuerzas ocultas de perturbación del

\footnotetext{
${ }^{18}$ Matsushita, op. cit., 272. Para ver los conflictos por la finalización de las intervenciones de la UF y LF, las declaraciones de la CGT en relación a la política exterior del gobierno y a favor de la democracia, la libertad de los presos políticos de marzo de 1944, las renuncias de dirigentes de la Comisión Pro-Unidad en abril, la prohibición del acto del 1ro de mayo y la participación en el del 25 del mismo mes, véase: Matsushita, op. cit., 265-282; Del Campo, op. cit., 203-220.

${ }^{19}$ Victorio Codovilla, Batir al Nazi-Peronismo, para abrir una era de libertad y progreso, Buenos Aires, Anteo, 1946, 9. Arnedo Álvarez, op. cit., 33. Isidoro Gilbert, La Fede. Alistándose para la revolución. La Federación Juvenil Comunista. 1921-2005, Buenos Aires, Sudamericana, 2009, 211-219. En este último se detalla con documentación y relatos de protagonistas, los preparativos, la organización y las persecuciones posteriores al fracaso de la acción insurreccional del movimiento. Iscaro, op. cit., 229-230.

${ }^{20}$ Codovilla, op. cit., 29-30.

${ }^{21}$ Horowitz, op. cit.; Doyon, op. cit.

${ }^{22}$ Del Campo, op. cit.; 205.
} 
campo político internacional". ${ }^{23}$ A ello se sumaron nuevos mecanismos de obturación de los sindicatos que no adherían políticamente a la nueva dinámica relacional, como fueron las intervenciones y el fomento a los sindicatos conocidos como paralelos. Los ejemplos más significativos del control sobre estructuras díscolas fueron, la Federación Gráfica Bonaerense (FGB), intervenida en marzo de 1944, y la Unión de Obreros y Empleados Municipales (UOEM), en junio. Los sindicatos comunistas que se vieron afectados por la política de fortalecimiento de otros sindicatos menores en aquellos momentos fueron la FONC, la FOIC, la UOT, el SOIM, el SUOM y la FOV, entre otros.

El desarrollo político del país en donde la actividad de la STyP y de Perón adquirían más relevancia, al igual que la presión de una oposición heterogénea, precipitaron los posicionamientos políticos de militares, partidos y del movimiento obrero, que se reflejaron en solicitadas, manifiestos y marchas durante $1945 .{ }^{24}$ Fueron los momentos en donde Edelmiro Farrell anunció la convocatoria a elecciones y el PC recuperó la legalidad. En el plano sindical, hacia mediados de año, los sindicatos comunistas, desde la FONC, comenzaron a coordinar con los socialistas actividades conjuntas.

El PC participó de la marcha del 19 de septiembre de 1945 por la normalización constitucional y la interpretó como el símbolo de "las reservas cívicas" y un "veredicto terminante y cabal: contra el gobierno de junio". ${ }^{25}$ La masividad fue evidente para el gobierno y para los organizadores. Entre los comunistas que encabezaron la manifestación se encontraban Rodolfo Ghioldi, Chiarante y Ernesto Giúdice quienes, al igual que el resto de los organizadores, confiaban en que el impacto político debilitaría definitivamente al gobierno. ${ }^{26}$ Los sucesos de octubre fueron analizados como resultado de la inestabilidad de fuerzas políticas y de la creciente presión militar y de las masas populares. Los días posteriores a la marcha de septiembre hasta el mes de octubre en la prensa del PC se celebraba la inminente caída de la "dictadura", mientras denunciaban los últimos intentos del G.O.U. para "salvar la situación". La renuncia de Perón se catalogó en esa línea, producida por la presencia del "pueblo en las calles que ha venido desde hace semanas expresando su voluntad democrática, unificándose en expresiones como la grandiosa Marcha de la Constitución y la Libertad". ${ }^{27}$ Su lectura sobre el 17 y el 18 de octubre como "manifestación de la esclavitud", producto de una mezcla de engaño a sectores "desclasados", a un sector de la clase obrera "fruto de la miseria impuesta por el capitalismo feudal" y a la "gente humilde", le sirvió para advertir la repetición, en versión nacional, de los métodos del fascismo europeo. ${ }^{28}$ La actividad del PC en la campaña electoral se centró, en base a su política frentista, en el acuerdo con los demás partidos para

\footnotetext{
${ }^{23}$ Discurso de Juan Domingo Perón, "Se inicia la era de la política social en la Argentina", 2 de diciembre de 1943, En: Carlos Altamirano, Bajo el signo de las masas (1943-1973), Buenos Aires, Emecé Editores, 2007, apéndice documental.

${ }^{24}$ Del Campo, op. cit., 283-294.

25 Orientación, Órgano central del Partido Comunista, (de acá en más Orientación) 26 de septiembre de 1945.

${ }^{26}$ Félix Luna, El 45, Buenos Aires, Sudamericana, 1971, 201.

${ }^{27}$ Orientación, 14 de octubre de 1945.

${ }^{28}$ Orientación, 24 de octubre de 1945.
} 
enfrentar la candidatura del "continuismo", lo que devino en la conformación de la Unión Democrática. Su discurso se caracterizó por un marcado corte reformista centrado en la denuncia sobre la falta de libertades, la defensa de la constitución, la democracia y la unión de todos los sectores progresistas. ${ }^{29}$ Aunque la bandera del PC fue la contradicción entre "democracia o fascismo", en el mundo sindical se apuntó a realizar un trabajo de unificación del sector "saliendo del marco de los ataques verbales", pero demostrando que el Partido Laborista representaba la debilidad del peronismo, por ser un conglomerado de elementos "sindicalistas colaboracionistas" y "radical-quijanista" que apoyaba al fascismo nacional. ${ }^{30}$

El triunfo de Perón en las elecciones, reconocido por el Partido, significó el inicio de un debate sobre el posicionamiento partidario. El PC se aprestaba a decidir si continuaba con su oposición abierta al peronismo o si se daba un nuevo programa para contrarrestar el influjo de la naciente fuerza en el movimiento obrero. La abierta oposición había fracasado, pero lejos estuvieron de plantearse el apoyo a un movimiento que, aún legitimado por la mayoría de los asalariados, seguía siendo para el PC, un conglomerado de fuerzas sociales contradictorias que, en esas condiciones políticas, relegaba a los trabajadores a un lugar de subordinación. ${ }^{31}$ Los cambios no fueron automáticos y los meses entre febrero y julioagosto, fueron momentos de transición. El Partido preparó su XI Congreso que supuso encarar nuevos análisis políticos, una nueva estrategia sindical y nuevas tareas de organización que estuvieran en concordancia con su frentismo, a la par que esperaba y observaba el planteo político de Perón al momento de su asunción y cómo se iban desarrollando las relaciones de fuerza dentro del movimiento obrero.

Las condiciones de posibilidad del PC en el sindicalismo entre los años 1943 y febrero de 1946 estuvieron signadas por las políticas estatales dirigidas a la regulación de las relaciones de trabajo y por las divisiones en aquellos gremios donde los comunistas tenían mayor influencia. Pese a estar proscripto y a la vertiginosa pérdida de espacios sindicales, el PC continuó trabajando por la unificación del movimiento obrero denunciando a los dirigentes gremiales, en su mayoría sindicalistas y una gran cantidad de socialistas, como traidores y colaboracionistas. En este aspecto, el rol cumplido por los comunistas desde las estructuras gremiales, del Comando Obrero Único, la Unión Obrera Local y en la Central Obrera Independiente resulta clave para comprender el devenir del PC en el sindicalismo. ${ }^{32}$

\footnotetext{
${ }^{29}$ Codovilla, op. cit., 10. En referencia a la ruptura del Frente Popular que según el análisis de Codovilla fue lo que permitió a Hitler invadir Francia.

30 Ídem, 34. Partido Comunista Argentino, Comité Ejecutivo. XI Congreso Nacional Ordinario días 14, 15, 16, 17 y 18 de agosto de 1946, Buenos Aires, 1946, p.11. Orientación, 31 de octubre de 1945.

${ }^{31}$ Partido Comunista Argentino, Comité Ejecutivo. XI Congreso Nacional Ordinario días..., pp. 1-8.

${ }^{32}$ El Patriota, Toda la nación unida para aplastar al nazismo, (de acá en más El Patriota) 29 de junio y 10 y 17 de agosto de 1945; La Hora, Diario de la Unidad Nacional, (de acá en más La Hora) 3 de diciembre de 1945; Orientación, 27 febrero y 13 de marzo de 1946.
} 


\section{Democracia y Unidad, una estrategia en tres planos}

Ocurrido el golpe de 1943, el PC afrontó la embestida a su participación sindical con las banderas de Democracia y Unidad. La primera, supuso la lucha antifascista pero también las denuncias sobre la represión, la persecución y las maniobras jurídicoadministrativas con las cuales los sindicatos comunistas lidiaron. ${ }^{33} \mathrm{La}$ segunda, fue la estrategia que, con cambios, se impulsó para construir espacios institucionales que permitieran algún campo de acción frente a la imposibilidad del normal funcionamiento de la dinámica sindical.

En diciembre de 1943, el PC emitió inmediatas advertencias sobre el peligro de "la intervención gubernamental en el movimiento obrero realizada en el cuadro de clausuras y trabas a los sindicatos, de persecución y encarcelamiento de dirigentes sindicales". Además, señaló las intenciones de Perón de "poner bajo la dirección de un gobierno reaccionario y pronazi, los intereses de la clase obrera que pretende estar defendiendo", a partir de allí explicaron el programa de unidad obrera que propusieron. ${ }^{34}$ Este debía ligar las luchas por las reivindicaciones económicas a "la defensa de los derechos políticos", bajo la bandera de lucha democrática, que por aquella época incumbió la creación de una única central obrera integrada por los gremios de fuerte influencia comunista. A los de la construcción, la carne, los metalúrgicos, los textiles, la FOGRA, la FATI, la Federación Obrera Polígráfica Argentina (FOPA), se sumaron los autónomos, la USA, y también los "Municipales y Empleados de Comercio- cuyo secretario general Ángel Borlenghi expresara en nombre de la Confederación General de Empleados en un documento público el anhelo unitario de los trabajadores del país- las recientes elecciones ferroviarias; integrantes de la CGT como C. Almarza y Roberto Testa". ${ }^{35}$ La propuesta de estos últimos dirigentes sindicales fue contestada positivamente por las federaciones y sindicatos comunistas, aunque el entusiasmo por el ofrecimiento de Borlenghi concluyó a la par que el PC lo acusó de divisionista a los pocos meses. ${ }^{36}$

Mientras tanto el PC exigió la reapertura de los sindicatos de la FONC, FOIC, UOT, Federación Obrera Metalúrgica y Minera, Sindicato de Obreros Panaderos, Sindicato Obrero Unidos del Puerto de la Capital, Federación Bonaerense de Trabajadores, SOIM y FOV a través de denuncias en los escasos órganos de difusión que mantuvieron y con presentaciones al Ministerio del Interior que, en algunos casos, fueron acompañadas con

\footnotetext{
33 Para el estudio específico del antifascismo en Argentina existen dos importantes obras de referencia: Andrés Bisso, El antifascismo argentino. Selección documental y estudio preliminar, Buenos Aires, CeDInCI Editores/Buenos Libros, 2007 y Ricardo Pasolini, Los marxistas liberales. Antifascismo y cultura comunista en la Argentina del siglo XX, Buenos Aires, Sudamericana, 2013.

34 Unidad Nacional, publicación del Comité Central del Partido Comunista, (de acá en más Unidad Nacional) diciembre de 1943.

${ }^{35}$ Unidad Nacional, primera semana de enero 1944.

${ }^{36}$ Unidad Nacional, segunda semana de mayo 1944.
} 
medidas de fuerza sectoriales y generales. ${ }^{37}$ En ellas se inscribieron la huelga general de Mar del Plata en diciembre de 1943 "contra las medidas pronazi del gobierno" que exigía, entre otras cosas, la reapertura de los locales sindicales y la libertad de dirigentes gremiales. ${ }^{38}$ En la misma línea se celebró el levantamiento de la huelga de la carne de octubre de ese año argumentando que con "nuevas conquistas y con la libertad de Peter (se logró) una vigorosa demostración de cómo el poder de la acción unida de la clase obrera y del pueblo es infinitamente mayor que el de artimañas obscuras y criminales". ${ }^{39}$ Lo mismo puede leerse en Unidad Nacional con respecto al paro del 26 de abril de 1944 "para reclamar la libertad de los presos"; los comunistas esgrimieron idénticos pedidos en la movilización con motivo del $1^{\circ}$ de mayo, que se realizó en Plaza Once, pese a la prohibición del acto propuesto por la CGT y la USA, y continuaron haciéndolo en diversas jornadas de protesta y huelgas de los meses subsiguientes. ${ }^{40}$ Para 1945, la FONC y la FOIC en Avellaneda, el 15 de mayo y los meses de abril y junio respectivamente, declararon huelgas con eje en reivindicaciones salariales y la libertad de su actividad y de sus dirigentes. Como Peter en octubre de 1943, Pedro Chiarante, secretario general de la FONC, fue dejado en libertad para entrevistarse con Mercante y Perón, pero el 12 de mayo el PC denunció su nuevo encarcelamiento, lo que llevó a renovadas medidas de fuerza, esta vez sin resultados. ${ }^{41}$ Para finales del mismo mes, la FOGRA, luego de un paro general para reclamar la postergación del laudo por parte de la STyP, movilizó a sus afiliados en protesta por la detención de su secretario general Manuel Moreira, el despido de 250 obreros y el asalto a su local. ${ }^{42}$ Este último episodio evidencia cómo los comunistas defendieron su representación sindical frente, no sólo a la represión, sino a lo que se denunció como maniobras jurídico-administrativas contra la independencia gremial por parte de un sector de dirigentes que negociaban la democracia interna a favor de los propósitos gubernamentales de lograr un interlocutor en el mundo gremial.

La detención de Moreira, que se sumó a la de Chiarante, junto con la mayoría de los dirigentes comunistas, evidenció para el PC la repetición de la falta de garantías en la que se encontraban. Denuncias que fueron expuestas, según el secretario general de la FONC a Perón cuando, en ocasión de la entrevista anteriormente citada, "le planteamos la situación del movimiento obrero en general. Le dijimos que es imprescindible la libertad más completa para que el movimiento obrero forje su unidad. Unidad e independencia, le afirmamos, son las condiciones básicas e irremplazables de una vida sindical que responda a los intereses y aspiraciones de los trabajadores. Esa independencia no existe desde el momento que el gobierno pretende regimentar a los sindicatos y ha colocado a hombres

${ }^{37}$ El Patriota, 7 de abril de 1945: se presenta un petitorio al ministro del Interior Contralmirante Teissaire. Conflicto de la Carne: El Patriota, 7 de abril, 8 y 15 de junio de 1945. Conflicto de la Construcción: El Patriota, 15 de junio de 1945.

${ }^{38}$ Unidad Nacional, diciembre de 1943.

${ }^{39}$ Unidad Nacional, 7 de octubre de 1943.

40 Unidad Nacional, segunda semana de mayo de 1944. El comunicado dice que "160.000 trabajadores paralizaron sus tareas" en la ciudad y provincia de Buenos Aires.

${ }^{41}$ El Patriota, 12 de mayo de 1945.

${ }^{42}$ El Patriota, 25 de mayo y 1 de junio de 1945. 
como Monsalvo y Montiel, sin representación de ninguna especie, al frente de la CGT". ${ }^{43}$ Peter no dejaba lugar a dudas acerca de los problemas que representaba la nueva coyuntura y que acompañaban el cierre de locales, las detenciones y la persecución en general: "ningún gremio ha sufrido los golpes que han sufrido los trabajadores de los frigoríficos. Su organización básica, es decir, las comisiones de sección fueron arrancadas de cuajo y encarcelados, centenares de camaradas que eran la base de la organización interna fueron despedidos mientras a los elementos peronianos se les da trabajo y se les protege en su acción antidemocrática". ${ }^{4}$

El denunciado colaboracionismo crecía así al amparo gubernamental que permitía acciones violentas en la dinámica sindical, es decir, asambleas, elecciones y movilizaciones. Por ejemplo, en la huelga en Berisso y Avellaneda en mayo de 1945, la FOIC emitió un comunicado que destacaba que "en la asamblea de La Negra en que fue resuelta la huelga, los elementos colaboracionistas enemigos de la FOIC, que pretenden asumir la representación de los trabajadores de la carne que ninguno les ha concedido, profirieron toda clase de amenazas para impedir la declaración que finalmente fue aprobada". ${ }^{45}$ Es en la misma línea que se registró al mes el asalto a la sede de la FOGRA. Antonio Cabrera, del Sindicato de Pintores, identificó a los asaltantes como elementos "desplazados del gremio y del movimiento obrero en general, que no se resignan, a ver terminada su acción perjudicial a los intereses obreros (...) con la aparente pretensión de procesar a la actual Comisión Administrativa, por supuesta malversación de fondos, se busca en realidad, paralizar las gestiones que realizaba el S.O.G para lograr la libertad de su dirigente M. Moreira y otros detenidos y las reivindicaciones que había reclamado el laudo, presentado a la Patronal y a la S. de Trabajo y Previsión". 46

Pero el colaboracionismo para el PC también se expandía porque "de un tiempo a esta parte han aflorado elementos que dicen representar a los intereses de la clase obrera argentina y que manejan palabras y sellos con una rapidez fantástica. (...) Frente a los problemas que agitan hoy al gremio de los frigoríficos, la FOIC en un manifiesto denuncia a los sujetos Cipriano Reyes, Lucas Dominguez, del Anglo; Díaz, de la Blanca; Julio Bubone, del Wilson; Chain de la Negra, como la expresión más baja de ese entreguismo que los trabajadores repudian". ${ }^{47}$ La consecuencia del amparo gubernamental, que concedió la representación gremial y propició el crecimiento de los sindicatos conocidos como paralelos, se hizo evidente cuando se produjo el levantamiento de las clausuras y las restricciones políticas.

A la reapertura, a mediados de junio, del local de la calle San Juan 3383 del SOC, se sumaron, el SOIM en julio que, luego de 2 años de clausura, reabrió su sede en Boedo 1954; la FOIC de Avellaneda lo hizo el 30 de julio en Italia 157 tras 21 meses "con la presencia de 500 delegados en representación de los frigoríficos de la zona”; el 10 de

${ }^{43}$ El Patriota, 12 de mayo de 1945.

${ }^{44}$ Orientación, 7 de noviembre de 1945.

${ }^{45}$ El Patriota, 14 de abril de 1945.

${ }^{46}$ El Patriota, 6 de julio de 1945. El 17 de agosto por orden judicial se ordenó la devolución del local y se dejó en libertad a Moreira.

${ }^{47}$ El Patriota, 28 de abril de 1945.

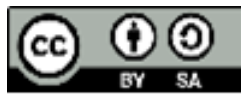


agosto, luego de dos años, el Sindicato Obrero de la Alimentación que, junto con la liberación de su secretario general Juan M. Yapichino, abrió un local en Anchorena 628; y a los días el Sindicato Obrero de la Industria del Pan junto con la liberación de su secretario Ángel González. ${ }^{48}$

Desde la apertura sindical a las elecciones de febrero del 1946, los sindicatos con influencia comunista comenzaron inmediatamente a reorganizar su actividad gremial con llamados a la renovación de carnet, a la realización de asambleas de delegados, a la vez que denunciaron "las restricciones oficiales e ilegales" que trababan el desarrollo de la dinámica sindical. La FONC, la FOV, el SOIM, el SUOM y la UOT dirigieron notas y memoriales al Ministerio del Interior pormenorizando las "medidas arbitrarias y los desórdenes no reprimidos" y exigiendo que "la Secretaría de Trabajo no se ingiera en las actividades de los sindicatos, evitando así la propaganda electoralista que desempeña dicha repartición oficial". ${ }^{49}$ También en aquellos meses, retomaron la presentación de petitorios para negociar reivindicaciones salariales. En este último punto se planteó que la imposibilidad de concretar los convenios colectivos era el resultado del accionar conjunto del gobierno y los sindicatos colaboracionistas. Pues, en el caso del primero, no reconocía la representación de los sindicatos al momento de mediar o de ratificar lo negociado directamente con la patronal. A los segundos se los acusó de obstruir y dividir a los trabajadores porque presentaban pliegos de negociaciones por separado. El secretario general del SOIM, Muzio Girardi, denunció en julio de 1945 a la "Unión Metalúrgica Argentina, entidad divisionista reconocida por la Secretaria de Trabajo y Previsión" como "responsable de haber hecho fracasar el pedido de mejoras que el gremio presentara desde agosto de 1944" ${ }^{50}$ Hacia fin de año, Girardi reclamó que la STyP "pretextaba no atenderlo por existir otro 'sindicato legal". ${ }^{51}$ Lo mismo ocurrió con el sindicato de la madera que durante varios meses de 1945 advirtió que "al crearse en forma artificial la llamada Unión Obrera Maderera se pretende, evidentemente, dividir al gremio, a fin de enrolarlo en una política 'colaboracionista'", 52 Frente a la elevación de un pliego de condiciones en el sector de la madera, los comunistas señalaban: "hacemos un llamado caluroso a los camaradas a fortalecer el Sindicato en todos los lugares de trabajo, desarrollando y creando amplias comisiones de unidad, que luchen por nuestro pliego y por la unidad obrera y la unidad democrática, condición básica de la victoria de la causa de la libertad y de la derrota del naziperonismo". ${ }^{53}$ Aunque siempre había sido un gremio signado por la incidencia de diversas corrientes políticas, los comunistas, con Vicente Marischi como principal referente, llamaban a organizarse en los talleres y destacaban la centralidad de las comisiones internas, aunque aclaraban que no dirigían el sindicato. ${ }^{54}$ Similar situación ocurría en aquellos meses, en sendos conflictos en el gremio gráfico y en el textil, en donde

${ }^{48}$ El Patriota, 15 de junio, 27 de julio, 10 de agosto y 17 de agosto de 1945.

${ }^{49}$ La Hora, 14 de noviembre y 13 de diciembre de 1945.

${ }^{50}$ El Patriota, 27 de julio de 1945.

${ }^{51}$ La Hora, 13 de diciembre de 1945.

${ }^{52}$ El Patriota, 28 de abril de 1945.

${ }^{53}$ Orientación, 19 de diciembre de 1945.

${ }^{54}$ Orientación, 26 de septiembre y 28 de noviembre de 1945. 
el PC hacía explícito su apoyo al proceder de las comisiones internas de las fábricas Peuser y Campomar. ${ }^{55}$

El consejo federal de la FONC también señaló el peligro del avance de los sindicatos "colaboracionistas" y las presiones sobre sus filiales para que abandonaran la federación y "se incorporen a la órbita de influencia de la Secretaria de Trabajo. Abundaron en tal sentido los 'generosos ofrecimientos' de ventajas materiales y las amenazas directas". En el mismo documento del 15 de julio de 1945 señalaron que "el movimiento obrero auténtico, que respeta su naturaleza independiente y su vocación antifascista, se plantea como tarea inmediata la organización de la unidad sindical y la constitución de una nueva central obrera que, excluyendo de si a los traidores colaboracionistas, impulse la acción unida de la clase trabajadora". Y exhortaba "a todas las Federaciones de industria, a los sindicatos, a los militantes que han sabido mantener la honra de su acción independiente, para crear a breve plazo una Comisión Organizadora de la Unidad Sindical que adopte por objetivo un programa de acción". 56 Fue inicialmente desde la FONC, en donde el PC históricamente estructuró su fortaleza sindical, que los comunistas lograron, pese a estar clausurada, trabajar por la unidad.

El relajamiento de las medidas represivas y el comienzo de la campaña electoral reforzó y a su vez cambió la estrategia unitaria que, como se dijo al principio del apartado llevó adelante el PC para construir espacios institucionales donde actuar. El llamamiento de la FONC no era nuevo, aunque sí lo era la composición buscada. El tipo de unidad perseguida por el Partido fue mutando conforme al desarrollo político del país. Así, desde el golpe, como se evidenció al principio del apartado, buscaron la unidad de todo el movimiento obrero organizado en una sola Central, lo que pronto se abandonó al concretarse el apoyo de algunos sindicatos al gobierno. Los comunistas entonces, se replegaron en dos estructuras endebles y de distinta naturaleza, una fue el Comando Obrero Único y la otra la UOL, luego, hacia mediados 1945, comenzaron a discutir su política sindical planteando un nuevo tipo de unidad, con la conformación de una Central Obrera Independiente.

El denominado Comando Obrero Único buscó aglutinar a los militantes comunistas y a todas aquellas fuerzas gremiales que se opusieran a brindar apoyo al gobierno para coordinar acciones sindicales. En este sentido funcionó, de modo clandestino, como el correlato en el plano gremial del movimiento político Patria Libre. Los puntos centrales de su programa establecieron las mismas banderas políticas y sindicales que el PC levantó durante aquellos años porque "solamente así la clase obrera está en condiciones de cumplir con su rol dirigente en el conjunto de fuerzas democráticas y antifascistas que, por el

\footnotetext{
55 En el caso de Peuser se felicitaba a la comisión interna por solicitar la expulsión de un obrero por 'divisionista'. Orientación, 7 y 14 de noviembre de 1945. En Campomar, sin embargo, la comisión interna se había puesto al frente del reclamo por el cobro del aguinaldo. La Hora, 14 de enero de 1946.

${ }^{56}$ El Patriota, 20 de julio de 1945. Se señalaban a Borlenghi, Telmo Luna, Manuel Pichel, Tesorieri, Montiel, Mozalvo, Argaña, Ugazio y Rubio como “traidores colaboracionistas". Y proseguían: "se han creado pseudo organizaciones, artificiales, paralelas a los sindicatos auténticos que no admiten la injerencia gubernamental ni silencian el cercenamiento de las libertades".
} 
camino de la unidad, se disponen a restablecer el régimen de la democracia". ${ }^{57} \mathrm{Su}$ actuación es díficil de rastrear, aunque se lo puede registrar como impulsor de la fallida huelga general del 31 de octubre de 1944 que, con consignas de reivindicaciones económicas y demandas ligadas al normal funcionamiento en el ámbito gremial, debía empalmar el descontento popular con el alzamiento insureccional de Patria Libre. ${ }^{58}$ Tras su fracaso, se lo encuentra en la prensa partidaria a mediados del año 1945 emitiendo un comunicado contra el acto del 12 de julio organizado por la Secretaría de Trabajo y Previsión. En su punto 6 declaraba: "por último, el COMANDO OBRERO ÚNICO en nombre de las Federaciones Nacionales y Sindicatos de la Capital e Interior del País que lo integran, reclama la inmediata vuelta a la normalidad Constitucional; libertad de los presos políticos civiles y militares; convocatoria inmediata a elecciones y libertad de prensa, palabra, reunión y asociación. Pide a los trabajadores que estén alerta y no se dejen sorprender por los empresarios electorales de la candidatura del Coronel Perón. Hace un ferviente llamado a todos los partidos y agrupaciones democráticas para que conjuntamente con la clase obrera se formalice cuanto antes la unión de todas las fuerzas democráticas y progresistas que recupere la normalidad constitucional y haga abortar los planes demagógicos y liberticidas de quienes abusan del poder y de los recursos del Estado con el abominable designio de imponer en lo interno y externo una política que es ajena a los sentimientos democráticos del pueblo argentino". 59 De allí en más sólo se tienen noticias de su disolución dos meses después cuando el PC obtuvo la legalidad. ${ }^{60}$

La siguiente organización en donde los comunistas recalaron, sin conformarla ni controlarla, fue la UOL. Desde ella pudieron articular denuncias contra la persecución de los sindicatos, reclamar la reapertura de sus locales y exigir la liberación de los dirigentes. ${ }^{61}$ La UOL fue impulsada principalmente desde el Sindicato Obrero Gastronómico, a través de su secretario general Moreira, en cuya sede de Paraná 555 funcionó hasta el momento que, como se dijo, fue asaltada. ${ }^{62}$ Entre sus objetivos y tareas, según Cabrera, miembro de la comisión administrativa, se encontraba "concretar la unidad de todas las fuerzas del trabajo", pero se aclaraba que la UOL perseguía la unidad del movimiento obrero sin

\footnotetext{
${ }^{57}$ En Iscaro, op. cit., 229.

${ }^{58}$ Gilbert, op. cit., 211-219.

${ }^{59}$ El Patriota, 27 de julio de 1945.

${ }^{60}$ Orientación, 26 de septiembre de 1945.

${ }^{61}$ El Patriota, 22 de junio de 1945. La UOL “integrada por el Sindicato Obrero Gastronómico, Sociedad de Chauffeurs, Camioneros y Afines, Unión Obrera Curtidores, Asociación de Músicos de la Argentina, Unión Obrera de la Bebida, Agrupación Obrera del Transporte Automotor de Pasajeros, Sindicato Obrero de Pintores y Fabricas de Pintura, Sindicato de Resistencia de Obreros Sombrereros, Sindicato Obrero de Confiteros, Pasteleros y Pizzeros, Sindicatos de Colocadores de Mosaicos, Azulejos y Lustradores". El Patriota, 3 de agosto de 1945. La UOL realiza una entrevista con funcionarios de la STyP y el 31 de julio emiten un comunicado "patrocinando una Delegación con representantes de las siguientes organizaciones obreras: Unión Obrera Textil, Federación Obrera del Vestido, Sindicato Obrero Metalúrgico, Sindicato Obrero Gastronómico, Federación Obrera Nacional de la Construcción, Federación Obrera de la Industria de la Carne". Puntualizando los pedidos en la libertad de actuación, esto es la reapertura de sus locales, la realización de asambleas.

${ }^{6}$ El Patriota, 29 de junio de 1945.
} 
distinciones sectarias o partidarias y se basaba en la independencia sindical, y era por ello que los gremios que la integraban "se oponen terminantemente a la unidad de tipo oficial sustentada en la pérdida de su autodeterminación gremial". ${ }^{63}$ Luego, a partir de la organización de la Comisión Nacional Pro-Central Obrera Independiente, la UOL se integró como un miembro más. ${ }^{64}$

Fue el dirigente de la construcción Chiarante quien figura en la prensa partidaria como uno de los impulsores de la constitución del nuevo tipo de unidad que realizaron desde "las 4 grandes Federaciones de industria, la FATI, la FONC, la FOGRA y la FOPA y la comisión nacional Pro-Central Obrera Independiente que ellas han creado", que funcionó en la calle Moreno 1467 de la Capital Federal. En aquella ocasión, Chiarante declaró: "ese llamado puede y debe plasmar rápidamente la unidad del movimiento obrero a través de todo el país. Los comunistas en el movimiento obrero no habremos de limitar nuestro esfuerzo para que esa Comisión abra rápidamente la perspectiva de la creación de la nueva Central Obrera que se propone". ${ }^{65}$ En el mismo sentido, Riego Rivas miembro de la FATI, secretario general de la Federación Gráfica Bonaerense y secretario general de la Comisión Pro Unidad Sindical Independiente, en referencia a la necesidad de crear la central denunció que "las interferencias del estado en la vida de las organizaciones, con vistas a someterlas a los propósitos oficialista, es de tal intensidad y persistencia a la corta o a la larga estas dejaron de existir como representantes de intereses definidos para transformarse en agentes de propósitos y ambiciones extrañas". En el mismo reportaje, Chiarante caracterizó a la CGT como “elementos 'colaboracionistas' (que) pretendieron aprovechar circunstancias para aparecer como dirigentes obreros, condición que perdieron junto con la moral cuando entraron al servicio de personas e intereses agenos a la clase obrera". ${ }^{66}$ Desde la prensa comunista se realizaron intensos llamados a la unidad en los meses subsiguientes, con disimiles resultados. En septiembre, la asamblea de delegados de la Federación Obrera Marítima aprobó una solicitada a su Consejo Directivo y a la USA para adherirse a la Comisión Pro Central Obrera; el pedido no era nuevo, ya en el congreso de la Federación los primeros días de noviembre de 1943 había peticionado la unidad sindical. ${ }^{67}$ Sebastián Marotta, secretario general de la FATI declaró que "en momentos en que la autonomía del movimiento sindical corre graves riesgos, cuando el Estado intenta interferir su acción independiente, poniendo en peligro su vida, y quitarle su originalidad, no puede haber otro pensamiento que el de la ratificación de su tradicional posición. Pensamos que el movimiento sindical no debe ni puede estar sujeto a ningún poder extraño a él mismo". ${ }^{6}$

En aquellos meses de 1945, la unidad propuesta en torno a la creación de la Central Obrera tenía su correlato en el trabajo gremial de base. La unidad debía ser plasmada en los

${ }^{63}$ El Patriota, 22 de junio de 1945.

${ }^{64}$ La Hora, 3 de diciembre de 1945. Declaran que son cerca de 20 sindicatos aglutinados en la UOL, en pos de la independencia sindical, contra el naziperonismo y la conformación de una Central Obrera Independiente.

${ }^{65}$ Orientación, 15 de agosto de 1945.

${ }^{66}$ El Patriota, 17 de agosto de 1945.

${ }^{67}$ Unidad Nacional, 4 de noviembre de 1943. El Patriota, 7 de septiembre de 1945.

${ }^{68}$ La Hora, 22 de noviembre de 1945. 
sitios de producción: “y así como las Federaciones de Industria procuran homogeneidad y dinamismo al movimiento obrero son las comisiones en los lugares de trabajo quienes aseguran la efectiva participación de las masas obreras en sus respectivas organizaciones (...). La organización básica en los propios lugares de trabajo, asegurando la efectiva participación de todos los obreros en la orientación y dirección del sindicato elimina las desviaciones a la burocracia, imprime el carácter combativo a la organización y resguarda la independencia de la política sindical de las influencias ajenas al movimiento obrero e impide, sobre todo, las injerencias gubernamentales". ${ }^{69} \mathrm{El}$ énfasis otorgado por Chiarante al trabajo en los sitios de producción no resultaba novedoso en la experiencia del PC pero tras el relajamiento del contexto represivo de mediados de año se retomaba. En el mismo sentido se pronunciaba la dirigente comunista metalúrgica Alba Tamargo: "quiero decir algunas palabras para los obreros y obreras metalúrgicos afiliados al Partido Comunista (...) En cada empresa donde trabaje un comunista debe ponerse al frente de la organización, con todo entusiasmo y dedicación. Debe ser el defensor permanente de las reivindicaciones de su personal y debe transformarse en su líder. No sólo debe estar organizado en el sindicato, sino que debe organizar todo el personal en el sindicato. Y, por último, el comunista debe preocuparse del buen funcionamiento de la comisión interna". ${ }^{70}$

Esa focalización del trabajo al nivel de planta debía estar complementada por la conformación de las comisiones barriales a las que los comunistas apuntaban a darles un nuevo impulso. Debían estar formadas por trabajadores de varios establecimientos, con un número entre 25 y 30 integrantes y ser el puntal para organizar nuevas fábricas y empresas. ${ }^{71}$ Así lo dejaba claro Cesar Ollero, obrero de la fábrica Klöckner: "pese a las pocas semanas de actividad ya tenemos formadas las comisiones barriales en casi todos los barrios de la Capital y zonas suburbanas. Estas comisiones desarrollan una gran actividad. Por ejemplo, la nuestra en Paternal está formada con representantes de todos los talleres del barrio. Se ocupa de la organización en todos los talleres de su zona. Hace reuniones de personales. Ayuda a formar las comisiones internas". ${ }^{72}$ Más allá de la exageración, la cita deja ver la intención del PC de coordinar la estrategia sindical en un triple plano: la central obrera, el restablecimiento del funcionamiento de las federaciones y sindicatos y el trabajo de base en las empresas y barrios. Ese trabajo de base debía convertir a cada comunista en "un impulsor de la unidad de todos los sectores democráticos y progresistas del país (...)" y denunciar que el "corporativismo peroniano ha logrado socavar la independencia de la organización (...)". ${ }^{73}$ Así, por ejemplo, se reclamaba la conformación de una "comisión unitaria de obreros auténticos de la empresa" en la metalúrgica TAMET frente a la declaración de una huelga por aumento de salarios, aguinaldos y reincorporaciones. ${ }^{74}$

El 7 de diciembre de 1945 se inauguraron las sesiones de la Conferencia Nacional pro Central Obrera Independiente "con presencia de doscientos veintiocho delegados" con

${ }^{69}$ Orientación, 22 de agosto de 1945.

${ }^{70}$ Orientación, 29 de agosto de 1945.

${ }^{71}$ Orientación, 29 de agosto de 1945.

${ }^{72}$ El Patriota, 7 de septiembre de 1945.

${ }^{73}$ Orientación, 5 de septiembre de 1945.

${ }^{74}$ La Hora, 11 de enero de 1946. 
las siguientes entidades: FONC, USA, FATI, FOPA, Confederación General Obrera del Vestido, Federación Obrera Metalúrgica y Minera Argentina, FOA, Unión General de Obreros del Tabaco, Federación de Trabajadores Santiagueños, Federación Obrera Provincial (Tucumán), Comisión Intersindical Pro Unidad (Mendoza), las UOL de Capital, Rosario, Córdoba, Paraná, Cañada de Gómez y la Comisión Pro Central Obrera Chaqueña. ${ }^{75}$ La separación entre sindicatos colaboracionistas y democraticos, no fue una bandera muy claramente levantada en las resoluciones de la Conferencia que, entre otras, estableció que "a los efectos de acelerar y organizar el proceso de unidad de la clase obrera sindicalmente organizada, recomienda a la Comisión de Unidad: que procure la unificación de los sindicatos paralelos que actualmente coexisten en algunas industrias; que impulse la constitución de organismos de relación; Uniones obreras comarcales, regionales y federaciones provinciales". ${ }^{76}$ Se fijó las fechas del 17 al 20 de abril de 1946 para la reunión del Congreso de la Central Obrera Independiente. El escenario político tras las elecciones se profundizaría y el carácter claramente minoritario de la Central creada con el impulso comunista no podía compararse con la representación de fuerzas que ya la CGT a mediados de 1945 había conseguido, nucleando al grueso de los sindicatos industriales, de comercio y de servicios y consolidando, en noviembre, la organización del Partido Laborista que ratificó la adhesión mayoritaria de los trabajadores en las elecciones de febrero de $1946 .^{77}$

Desde su legalización los comunistas buscaron mantener tanto el trabajo partidario en los gremios, como el trabajo estrictamente sindical. Así se desprende del informe presentado por Juan José Real, secretario de organización del PC, frente a la V Conferencia Nacional: "para el mejor logro de la finalidad que nos proponemos, es decir, el desarrollo de una fuerte organización partidaria en las empresas, será necesario que nuestra labor sea coordinada con el trabajo de los sindicatos. No para que haya competencia entre Partido y Sindicato, como ocurre a veces, sino para coordinar ambas actividades que no se repelen entre sí, sino que, por el contrario, se complementan. Ello no significa confundir los términos: la organización partidaria debe desarrollar su labor independientemente del sindicato, siendo obligatorio, sin embargo, que todos los comunistas sean miembros del sindicato y trabajen tesoneramente en su organización y desarrollo. La célula comunista, por otra parte, no debe ni puede suplantar al sindicato. Entre su propaganda y la del sindicato debe haber estricta diferencia, entre su labor organizativa y la sindical, asimismo". ${ }^{78}$ Florindo Moretti, miembro del Comité Central y cuadro gremial ferroviario, también mencionaba la importancia que aquella Conferencia partidaria le había otorgado a los comités en las empresas como método de recuperar el influjo que reconocían haber perdido entre la clase trabajadora. ${ }^{79}$ El mismo énfasis con el que el cuadro de la construcción, Pedro Tadioli, llamaba a lograr la unidad de la clase obrera fortaleciendo "el movimiento sindical libre e independiente". 80

${ }^{75}$ La Hora, 5 y 12 de diciembre de 1945.

${ }^{76}$ La Hora, 11 de diciembre de 1945.

${ }^{77}$ Doyon, op. cit., 162-184.

78 Orientación, 2 de enero de 1946.

${ }^{79}$ Suplemento dedicado al 28 aniversario del Partido Comunista.

${ }^{80}$ Orientación, 16 de enero de 1946.

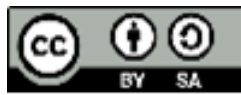


Como se señaló al comienzo del trabajo los cambios no fueron automáticos, los meses de febrero a agosto de 1946, momento donde el Partido realizó su XI Congreso, fueron de transición política y sindical. El Partido preparó su Congreso evaluando qué tipo de unidad sindical iba a buscar, para ello fue importante la experiencia que los cuadros sindicales fueron desarrollando en los últimos meses. En las discusiones previas a la realización del XI Congreso se ofrecía un balance sobre la actuación gremial en los años inmediatos. Allí se caracterizaba el proceder como producto de desviaciones sectarias y oportunistas que provocaron un excesivo aglutinamiento en torno a la dirección de Patria Libre en detrimento del trabajo unitario de base. Además, puntualizaron en tres momentos específicos en donde podían evidenciarse con claridad los errores cometidos: la huelga frigorífica de septiembre de 1943, la huelga general del 31 de octubre de 1944 y la crisis de gobierno de inicios de octubre de 1945. Allí también se destacaba el crítico balance sobre el proceder partidario que se había hecho en la reunión del Comité Central de octubre de 1945 (en la que participaron dirigentes provinciales partidarios, responsables del movimiento sindical y dirigentes recientemente excarcelados) y el rumbo que debía, en algún sentido, retomarse: "se puso el acento sobre la necesidad de consolidar y desarrollar los sindicatos sobre la base de la lucha por las reivindicaciones inmediatas y de organizar el movimiento de unidad nacional sobre la base de comités unitarios en los lugares de trabajo y de habitación de los obreros y de la población en general". ${ }^{81}$ Los errores y el balance no evitaron las críticas internas de sectores que intentaron ir más allá de aquellas problemáticas analizadas por la dirigencia partidaria. La expulsión tanto de la célula ferroviaria de Barracas como del grupo de intelectuales donde se desatacaron Rodolfo Puiggrós y Eduardo Antesano, luego de la discusión del Congreso, reafirmaron la voluntad monolítica de la dirección y la formación de una organización que buscó ponerla en cuestión, el Movimiento Obrero Comunista. ${ }^{82}$

\section{Conclusión}

Revisar la historia del PC en su vínculo con el sindicalismo a partir de 1943 supone indagar una experiencia en la que la pérdida de incidencia comunista en el movimiento obrero, principalmente industrial, se torna evidente. Entendemos que uno de los elementos centrales que deben sopesarse al momento de valorar dicho fenómeno es el de la potencia con la que irrumpió el nuevo vínculo entre el sector encabezado por Perón y el sindicalismo. Esa relación, construida al amparo estatal, incluyó un complejo entramado de satisfacción de demandas sociales y salariales, regulación de las relaciones entre capital y trabajo, búsqueda de control y centralización del modelo gremial y la persecución y represión a dirigentes gremiales junto a la elaboración de mecanismos de obturación de los

\footnotetext{
${ }^{81}$ Partido Comunista Argentino, Comité Ejecutivo. XI Congreso Nacional Ordinario días..., 9.

${ }^{82}$ Documentación interna del partido sobre la expulsión de la célula ferroviaria: Archivo CCC. Omar Acha, La Nación Futura, Rodolfo Puiggrós en las encrucijadas argentinas del siglo XX, Buenos Aires, Eudeba 2006; Samuel Amaral "Peronismo y marxismo en los años fríos: Rodolfo Puiggrós y el Movimiento Obrero Comunista, 1947-1955”, en Investigaciones y Ensayos, 50, 2000, 171-194.
} 
sindicatos que no adherían políticamente a la nueva dinámica relacional. La propuesta de nuestro trabajo fue observar la estrategia gremial del PC frente a este escenario y profundizar específicamente esta respuesta, que la bibliografía había encarado de modo general.

Bajo la estrategia política del frente popular, materializada con las resoluciones del VII Congreso de la Comintern, se habilitaron acuerdos con las fuerzas obreras 'reformistas', e incluso con los sectores 'progresistas' de la burguesía, que posibilitaron la construcción de alianzas bajo preceptos antiimperialistas y antifascistas. Esta decisión tomada en la III Conferencia Nacional partidaria, realizada en Avellaneda en octubre de 1935, subordinó a los trabajadores a los intereses de la burguesía nacional y eso se evidenció en las posiciones asumidas en el período. En este sentido, el PC buscó plasmar sus principios rectores de Democracia y Unidad que entendía le permitía la abierta denuncia y lucha contra lo que identificaban como fascismo y la articulación de estructuras y espacios de acción en el universo sindical. Así, pudimos identificar tres niveles de concreción. El primero, la creación de instituciones que le permitieran aglutinar a los sectores gremiales opuestos al gobierno. Se enmarcaron en este nivel de búsqueda de elaborar un polo para enfrentar al gobierno y sus políticas en el gremialismo: los intentos de conformar un programa de unidad obrera en diciembre de 1943, la creación del Comando Obrero Único, el funcionamiento de la Unión Obrera Local y, por último, los esfuerzos por corporizar la Central Obrera Independiente. El segundo nivel, se basó en los continuos intentos de restablecimiento del funcionamiento de las federaciones y sindicatos en donde conservaban presencia para poder contrarrestar las clausuras, intervenciones, detenciones y fomento de sindicatos denominados paralelos o apoyo a otros ya existentes proclives al acuerdo con Perón, que entendían lesionaban la independencia del movimiento obrero. El último de los niveles de esta estrategia fue el trabajo de base en las empresas y en los barrios. Durante los meses posteriores al golpe de Estado, y con marcado énfasis tras la legalización del Partido a mediados de 1945, los comunistas enfatizaron la centralidad del trabajo de base sindical, con eje en las comisiones internas, y partidario, estructurado en células, como método de conservar la incidencia entre los trabajadores. Estos reportorios de base, en los cuales podían mostrar pericia y una tradición de cerca de dos décadas, fueron el modo a través del cual buscaron constituir ciertos vasos comunicantes con los obreros que rápida y tendencialmente se identificaban con la propuesta enarbolada por Perón.

En suma, hacia 1943 la presencia del PC en el mundo gremial se encontraba aún en ascenso. En la dirección de los principales sindicatos industriales y codirigiendo la CGT, ya fragmentada, junto a un sector de los cuadros socialistas, podía mostrar sólidas bases en el universo gremial. Aún más, esa experiencia no parecía mostrar signos de agotamiento. Pero el golpe de junio de 1943 implicó un cambio abrupto en el mundo del trabajo. De conjunto, las estrategias aquí narradas se aplicaron con mucha dificultad y se mostraron infructuosas para interpretar ese cambio de escenario delineado por el Estado y caracterizado por un cambio de modelo sindical, satisfacción de demandas laborales y una fuerte represión que tuvo a los comunistas entre sus principales víctimas. El rápido y exitoso vínculo entablado por Perón desde el Estado con los trabajadores junto a la fuerte represión conformaron un 
escollo insalvable para un PC que, además, elaboró por aquellos meses un débil análisis de los sucesos.

\section{Bibliografía}

- Acha, Omar, La Nación Futura, Rodolfo Puiggrós en las encrucijadas argentinas del siglo XX, Buenos Aires, Eudeba, 2006.

- Altamirano, Carlos, Bajo el signo de las masas (1943-1973), Buenos Aires, Emecé Editores, 2007, apéndice documental.

- Amaral, Samuel, "Peronismo y marxismo en los años fríos: Rodolfo Puiggrós y el Movimiento Obrero Comunista, 1947-1955”, en Investigaciones y Ensayos, 50, 2000, 171194.

- Arévalo, Oscar, El Partido Comunista, CEAL, 1983.

- Arnedo Álvarez, Gerónimo, Cinco Años de lucha, entre el X y el XI Congreso, Buenos Aires, Anteo, 1946.

- Bisso, Andrés, El antifascismo argentino. Selección documental y estudio preliminar, Buenos Aires, CeDInCI Editores/Buenos Libros, 2007.

- Camarero, Hernán, A la conquista de la clase obrera. Los comunistas y el mundo del trabajo en la Argentina, 1920-1935, Buenos Aires, Siglo XXI Editora Iberoamericana, 2007.

- Camarero, Hernán, Comunismo y movimiento obrero en la Argentina, 1914-1943, tesis de doctorado, Universidad de Buenos Aires, 2008.

- Ceruso, Diego, La izquierda en la fábrica. La militancia obrera industrial en el lugar de trabajo, 1916-1943, Colección Archivos, Buenos Aires, Imago Mundi, 2015.

- Codovilla, Victorio, Batir al Nazi-Peronismo, para abrir una era de libertad y progreso, Buenos Aires, Anteo, 1946.

- Contreras, Miguel, Memorias, Buenos Aires, Testimonios, 1978.

- Chiarante, Pedro, Pedro Chiarante, ejemplo de dirigente obrero clasista, Buenos Aires, Fundamentos, 1976.

- del Campo, Hugo, Sindicalismo y peronismo. Los comienzos de un vínculo perdurable (1983), Buenos Aires, Siglo Veintiuno Editores, 2005.

- Di Tella, Torcuato, Perón y los sindicatos. El inicio de una relación conflictiva, Buenos Aires, Ariel, 2003.

- Doyon, Louise, Perón y los trabajadores. Los orígenes del sindicalismo peronista, 19431955, Buenos Aires, Siglo Veintiuno Editora Iberoamericana, 2006.

- Durruty, Celia, Clase obrera y peronismo, Buenos Aires, Pasado y Presente, 1969.

- Fava, Athos, Qué es el Partido Comunista, Buenos Aires, Sudamericana, 1983.

- Germani, Gino, "El surgimiento del peronismo: el rol de los obreros y de los migrantes internos", Manuel Mora y Araujo e Ignacio Llorente (comps.), El voto peronista. Ensayos de sociología electoral argentina, Buenos Aires, Sudamericana, 1980, 87-163.

- Gilbert, Isidoro, La Fede. Alistándose para la revolución. La Federación Juvenil Comunista. 1921-2005, Buenos Aires, Sudamericana, 2009.

- Haupt, Georges, El historiador y el movimiento social, Madrid, Siglo XXI, 1986. 
- Horowitz, Joel, Los sindicatos, el Estado y el surgimiento de Perón, 1930-1946, Buenos Aires, Eduntref, 2004.

- Iscaro, Rubens, Historia del movimiento sindical, tomo 2, Buenos Aires, Fundamentos, 1973 (versión anterior: Origen y desarrollo del movimiento sindical argentino, Buenos Aires, Anteo, 1958).

- Korzeniewicz, Roberto, "Las vísperas del peronismo. Los conflictos laborales entre 1930 y 1943”, Desarrollo Económico. Revista de Ciencias Sociales, 131, 1993, 323-354.

- Luna, Félix, El 45, Buenos Aires, Sudamericana, 1971.

- Matsushita, Hiroshi, Movimiento Obrero Argentino, 1930-1945: Sus proyecciones en los orígenes del peronismo, Buenos Aires, Hyspamérica, 1986.

- Murmis, Miguel y Juan Carlos Portantiero, Estudios sobre los orígenes del peronismo. [Edición definitiva] (1971), Buenos Aires, Siglo Veintiuno Editores Argentina, 2004.

- Nadra, Fernando, La religión de los ateos, reflexiones sobre el estalinismo en el Partido Comunista Argentino, Buenos Aires, Puntosur, 1989.

- Pasolini, Ricardo, Los marxistas liberales. Antifascismo y cultura comunista en la Argentina del siglo XX, Buenos Aires, Sudamericana, 2013.

- Puiggrós, Rodolfo, Historia crítica de los partidos políticos argentinos, Buenos Aires, Argumentos, 1956.

- Ramos, Jorge Abelardo, El partido comunista en la política argentina, Buenos Aires, Coyoacán, 1962.

- Real, Juan José, 30 años de historia argentina (acción política y experiencia histórica), Buenos Aires-Montevideo, Actualidad, 1962.

- Schiavi, Marcos, El poder sindical en la Argentina peronista (1946-1955), Buenos Aires, Imago Mundi, 2013.

- Torre, Juan Carlos, La vieja guardia sindical y Perón. Sobre los orígenes del peronismo, Buenos Aires, Sudamericana, 1990. 